\title{
A Cognitive Approach to Teaching English for Special Purposes (ESP)
}

\author{
Natalya Davidko \\ crossref http://dx.doi.org/10.5755/j01.sal.0.18.414
}

\begin{abstract}
Cognitive science today makes it possible to combine independent studies under the auspices of one focal problem - the workings of the human mind in knowledge acquisition. Foreign language teaching draws heavily on linguistics, psychology, and philosophy. In this article we come up with a cognitive approach to teaching language for special purposes. The focus of our attention is on terms belonging to a specific domain (options). The acquisition of terminology in a foreign language presupposes knowledge of a non-linguistic conceptual structure (conceptual content) and means of verbalization (linguistic content). To expose the conceptual content of an individual term we employ the notion of qualia which allows us to study a term from four cognitive aspects. In order to give students a holistic picture of the domain in question we make use of cognitive modeling which means constructing an abstract "infrastructure" of the subject area and showing possible links among its elements. The objective of teaching is to help students create a "personal construct" - a personal model of knowledge - which enhances their information processing capacity and lays down the foundation of their future progress in advanced knowledge acquisition and comprehending and generating professional discourse.
\end{abstract}

Key words: cognitive science; personal construct; concept development; qualia; cognitive model; mental representations; cognitive teaching.

\section{Introduction}

Globalization and exposure to stiff competition in labor markets make people revisit their views on education in general and foreign language learning in particular. Many young people give preference to multilingualism because it is common belief that more languages enhance one's employability, hold out a promise of faster promotion and better achievement levels, and increase chances of success.

The English language for business communication remains a must for the overwhelming majority of learners. BUSINESS today is many things: stock market, banking, ethics, and marketing, to mention but a few. As a result, English for business communication is highly compartmentalized, i.e. falls into separate subject areas (slots) worthy of focused attention. Therefore business classes must be tailored to students' needs and should start with the acquisition of terminology which lies at the core of any specialized discourse and professional communication and serves as "mutual knowledge" or "shared information" for professional people.

We presume that a serious didactic approach may be worked out only if it is based on a sound linguistic theory and psychological researches. Cognitive science - a number of independent studies interested in the workings of the human mind - opens up new venues for linguistic analysis and foreign language teaching. Cognitive linguistics as well as cognitive psychology and philosophy give us a better insight into what and how we are teaching: it emphasizes the innate relationship between mind and language, cognition and verbalization (Thagard, 2005, p.4). The characteristic idea of cognitive linguistics is that in order to achieve an adequate level of knowledge "we must not only describe concepts and categories with an abstract definition, but we should take into account the things that the definition is about" (Geeraerts, 2006, p.1).
The basic tenet of cognitive didactics and psychology is that learning involves an active construction of knowledge on the part of students: "all meaningful learning is a form of active knowledge construction" (Derry, 1996, p.169).

Terms - specialized words or expressions used in a particular profession or activity to designate concepts are the most important part of ESP acquisition and teaching them is not all plain sailing. The classical view on terminology was formulated by Wüster (1974) of the Vienna school. This theory stipulates five things: the priority of concepts, a logically structured conceptual system, clear-cut definitions, the naming function of terms, and the permanent concept/ term assignment. We assume that terms are specific lexical units in which linguistic content is so fused with non-linguistic conceptual content that any meaningful teaching must include the conceptual aspect as its objective.

The aim of the article is to suggest a specific teaching approach which employs two cognitive tools - qualia and cognitive model - in addressing conceptual content, expose their advantages in concept explication and show the possibilities they open up for structuring professional knowledge and enhancing learning efficiency and effectiveness. Novelty of this approach lies in the fact that cognitive tools are applied to classroom teaching.

\section{Theoretical Background}

The cognitive paradigm allows implementing an interdisciplinary approach when addressing the question of knowledge acquisition. The cognitive approach focuses on mental processes of learning where perception and computation of information are postulated to be dependent on prior knowledge, and language is regarded as a 'vehicle' providing access to cognitive content. Can the opposite be true? We think it can: comprehension and acquisition of 
cognitive content paves the way to a faster and easier learning of a special language.

Before we discuss tools of cognitive teaching we find it necessary to summarize our views on the following questions: What is knowledge? What is learning? What is language knowledge? How is knowledge acquired and stored?

\section{The essence of knowledge}

When learning English for Special Purposes students are faced with double difficulty: WHAT to say and HOW to say. The difficulty stems from the existence of two types of knowledge: KNOW THAT (often called epistemological or propositional knowledge) and KNOW HOW TO (often called procedural knowledge). The differentiation of knowledge into several types goes back to the philosophy of knowledge. Illuminating insights into the essence of knowledge are found in the works of the philosophers of the XVII-XVIII centuries: J. Locke, J. Berkeley, D. Hume and I. Kant. I. Kant distinguished between seven degrees of knowledge:
1) merely to have some knowledge;
2) to have an idea consciously;
3) to know something in comparison with other things, according to identity as well as to difference;

4) to know something consciously or to apprehend it;

5) to understand something, or to conceive by means of concepts;

6) to apprehend something through the reason, or understanding content;

7) to comprehend something in that degree which is sufficient for a certain purpose (Kant, 1908, pp.258-259).

Crowning it all is Kant's assertion that "knowledge is a system and not merely an aggregate. Consequently, knowledge must be arranged according to well-considered rules and after a method" (ibid., p.259).

It will not be an exaggeration to say that I. Kant has laid down the foundation for modern cognitive didactics. His ideas of conscious acquisition of knowledge, the role of concepts in understanding, and selective approach to the content of knowledge aimed at achieving a goal are a hallmark of modern pedagogical thinking. Modern educators single out four types of knowledge: factual knowledge which comprises the basic elements of a subject students must know to be acquainted with it; conceptual knowledge which consists of the interrelations among these basic elements that enable them to function together; procedural knowledge which means knowing how to do something and having skills for it; and meta-cognitive knowledge which includes the skills for elaborating strategies for how to accomplish tasks or how to understand presented information (Anderson, 2001). So, in modern science knowledge does not only involve knowing some facts or information, but the ability to apply this information to various situations for achieving various goals. The acquisition of these types of knowledge would lead to the conception of two types of competences: cognitive competence - knowing the subject matter — and linguistic competence that is the ability to use and understand the meta-language of the area in question.

\section{The essence of learning}

The cognitive approach adopted in this article draws heavily on the cognitive constructivist learning theory which is based on the premise that learning is an active individual process involving students' participation in knowledge acquisition (empathy). The constructivist theory is based on George Kelly's (1955) idea of the 'personal construct' (internal models of the world) as the basic unit of mental cognitive structure that a person deliberately creates in the process of cognition and through which s/he interprets, understands, and evaluates events, situations, and new information. Later research in psychology (Ericsson \& Smith, 1991; Hoffman, 1992) showed that people with developed personal constructs - those that have a more complex hierarchical organization and contain more links among its elements, hence are more differentiated and integrated - have greater expertise in a certain field/ domain. Experts differ from laypersons and novices in that they recall information from memory more quickly, organize and use it more quickly, and apply it to new situations pertinently. True, personal constructs differ from person to person depending on his/ her cognitive abilities, learning styles, individual differences and affective factors. Since knowledge may be built on faulty beliefs and misconceptions, the teacher's goal is to ensure that personal constructs don't deviate much from the standard educational model and help students to gradually form more complex constructs.

Learning is a cognitive process. In the process of cognition concepts (scientific and everyday) are formed and encoded "in the words of a language" (lexicalization) (O'Grady, 1997, p.280) related to particular conceptual content. Natural languages supply different ways for encoding conceptualizations. Cognitive linguists claim that concepts do not exist separately in our mind but are brought together into conceptual systems by experience (Croft \& Cruse, 2004, p.7) and contain non-linguistic information. At different times various names have been offered: frame (Fillmore, 1982), schema (Anderson, 1977), script (Schank, 1977), ideals (Bregman, 1977), experiential gestalt (Lakoff, 1980), cognitive model (Lakoff, 1987; Evans, 2009), cognitive complexity (Burleson, 1987), and some others. Scientists stress that conceptual systems are "capable of organizing and classifying every imaginable aspect of our experience" (O’Grady, 1977, p.276).

\section{Modern views of language knowledge}

According to cognitive scientists, language knowledge is not different from any other type of knowledge, so it is acquired, stored and retrieved according to the same structural cognitive principles that operate in other areas. Knowledge in the human mind is reflected in mental or cognitive representations - the basic units of human knowledge stored in the mind. Mental representations are information-bearing structures with which operations can be performed in order to build recognition patterns conducive to more complex knowledge (Paivio, 1990, 
p.18). Mental representations vary in the degree of abtractness and relate to words, concepts and situations. There are at least two types of mental representations: verbal and conceptual. A person first develops a verbal representational system in his native language whereas bilingual persons have two verbal representational systems which are functionally connected to a common cognitive or conceptual system. So the learner must develop "new mental representations and develop facility at accessing those representations in a variety of circumstances" (Archibald, 1997, p.535), and it is "essentially important to learn the second language in direct association with appropriate referents" (Paivio, 1990, p.252).

\section{Cognitive model of learning}

In order to successfully teach LSP we must understand how knowledge is acquired, organized and stored in the human mind, what factors affect it and make learning more efficient. Among the many theories and models we have chosen the cognitive model of learning introduced by Derry (1990) as instrumental for our reasoning. The model sheds light on the process of acquiring meaningful and useful knowledge which gives teachers a clue to how the teaching process may be organized.

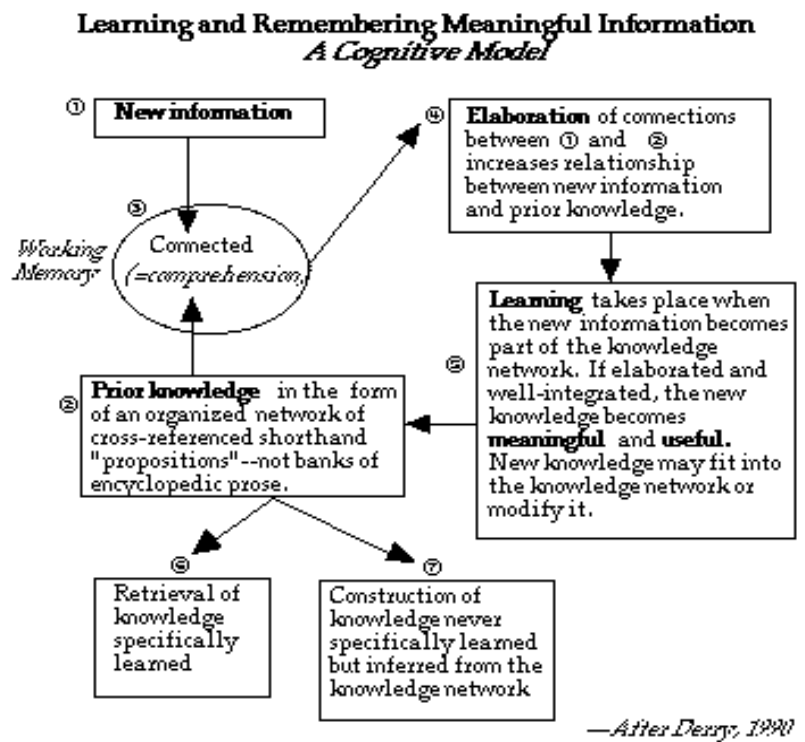

Fig. 1. Cognitive Model of Learning.

As we can see, in this model prior knowledge (2) plays a very important and active role in acquiring new knowledge and comprehending new information. Prior knowledge means previously accumulated mental representations of various kinds referring to a certain domain or domains and serving as building blocks for further expansion of knowledge, interpretation of new experience and mutually satisfactory communication. Novel objects are categorized, filtered through and fitted into an already existing conceptual system, in other words, success in learning depends on whether the learner can combine the new with the known.

In his work the teacher may be confronted and have to deal with two possible situations. First, the student has prior knowledge about the subject matter (in his native language) so he simply has to acquire new mental representations (in a foreign language) though it is not a simple task in itself. In this case it is advisable that the teacher check what students already know or remind them about it. The alternative situation presents more of a challenge. Students lack the prerequisite knowledge so the teacher has to help them build general/ specialized knowledge, form mental representations of concepts in question and simultaneously provide means of expressing new notions.

\section{Cognitive Teaching}

Concepts represent typical entities (prototypes) that have bundles of typical features which we propose to describe with the help of 'qualia'. Since the term is used in different meanings we deem it necessary at this point to explain at some length our understanding of the term.

\section{What is Qualia?}

The term has been used by philosophers, psychologists and linguists. Though all scientists claim that it helps to answer the question "what's it like?" about an object, the term has a least two distinct interpretations. The first interpretation goes back to J. Locke's secondary qualities of objects such as colors, aromas, tastes, sounds (Locke, 1849) which have traditionally been described in the philosophy of mind as intrinsic qualities of conscious experience. The term qualia was introduced in the philosophical literature by C. Lewis in 1929 (Lewis, 1929). Since its introduction there have been heated arguments whether a quale is something in the brain or something in the external world, i.e. some properties or "powers" of an object that can produce an idea in our minds. But the question whether redness exists in our minds or on a flowerbed of red roses still remains unresolved.

Linguistics seems to have chosen a more fruitful approach to qualia which can be traced to Aristotle's fundamental or primary causes (modes of explanation). Aristotle considered that a man has knowledge if he knows the primary cause, and he spoke of causes in four ways:

\begin{abstract}
One cause we say to be the substance and the essence (the primary 'why') and the second is the matter and substrate, and the third is that from which comes the beginning of the change, and the fourth is the opposite cause to this, the 'wherefore' and the good (for this is the end of all coming into being) (Aristotle, 1998, p. 12).
\end{abstract}

In his book "Generative Lexicon" J. Pustejovsky drawing on Aristotle's primary causes came up with his idea of qualia structure to be used in linguistic analysis. He postulates that Qualia structure specifies four essential aspects of a word's meaning permitting a much richer description of a concept:

- Constitutive: the relation between an object and its constituent parts;

- Formal: that which distinguishes it within a larger domain;

- Telic: its purpose and function;

- Agentive: factors involved in its origin or "bringing it about"

Lexical items encode semantic information in the qualia which "drives our understanding of an object or a relation 
in the world" (Pustejovsky, 2001, p.76) because qualia structure explains a word "as denoting a particular concept not as a lexical unit used in the language" (ibid., p. 85). His ideas gave an impetus to a series of very interesting researches on homonymy, metonymy, compounds, nominal and prepositional phrases, possessive case, text interpretation in different languages. However, qualia structure has been unnoticed by language teachers, though Pustejovsky emphasizes its potent explanatory role. We intend to apply qualia structure to teaching terminology and show how it can be used.

\section{Concept development via cognitive model}

The dominant view held by cognitive scientists is that knowledge is encoded as patterns of interconnected conceptual systems in the human brain. Conceptual development involves strengthening and enlarging these connections. In everyday life patterns are derived and multiple relationships are established from repeated experience. However, in classroom teaching, given the limited number of classes, simulation patterns should be worked out by the teacher. These simulation patterns must reflect the properties of the real environment. A cognitive tool that meets these requirements is cognitive modeling. By cognitive model we mean a theoretical construct which represents "a coherent non-linguistic knowledge structure captured from multimodal experience" (Evans, 2009, p.107). It relates to a specific domain and is an approximation to a phenomenon or process existing in reality but simplified for teaching purposes.

\section{Subject Matter}

For a more detailed analysis we have chosen a field of notable difficulty - OPTIONS. Options are part of a broader domain of financial tools called derivatives. This area of business activity contains a large number of words and expressions used by professionals and experts which, in our opinion, have different didactic value. With interest in and trust to options waxing and waning throughout their long and colorful history and derivatives today being named a culprit in the recent financial crisis and labeled as "financial weapons of mass destruction", it is evident that no Business English class can bypass this topic. The teacher's task is to make this topic comprehensible and accessible by revealing the controversial nature of derivatives and showing what features make them useful instruments and whether or not their danger is exorbitant.

\section{Vocabulary Selection}

Vocabulary selection is important for cognitive modeling as we must establish what attributes populate the chosen domain. To this end we analyzed a vast corpus of various sources: the media both traditional and electronic), glossaries, manuals, specialized textbooks (see Appendix 1). They vary in the number and variety of terms, ways information is presented, and language difficulty. As a result, we came to the conclusion that academic textbooks for students studying financial markets and manuals compiled by professionals for non-professionals interested in investing best serve our objectives: glossaries seemed to us too decontextualized and very few newspaper articles meet the requirements of clarity and simplicity necessary at the initial stage of learning. Textbooks and manuals, on the contrary, contain clear explanations, precise definitions, and the vocabulary that makes up the core of the terminological system and reflects the cognitive structure of the conceptual system in question. Thus, we have selected a compact list of recurrent lexical units which constitute base knowledge for learners and are sufficient for understanding specialized texts and producing simple discourse.

\section{Explaining Concepts via Qualia Structure}

When explaining individual concepts to learners, for example, what an option or a forward is, we resort to qualia-structure. The aim is to help students apprehend the concept and form a mental representation of it. We start from the conceptual content and by asking the questions involve students in concept explication.

Table 1. Qualia Structure Analysis of the Term 'Option'.

\section{OPTION}

\begin{tabular}{|l|l|l|}
\hline \multicolumn{1}{|c|}{$\begin{array}{c}\text { Qualia } \\
\text { Structure }\end{array}$} & \multicolumn{1}{c|}{ Conceptual Content } & \multicolumn{1}{c|}{ Lexical Content } \\
\hline $\begin{array}{l}\text { What is it? } \\
\text { (formal) }\end{array}$ & It is a contract giving the right to buy or sell an asset; & Call option; put option \\
\hline $\begin{array}{l}\text { What is it made of? } \\
\text { (constitutive) }\end{array}$ & $\begin{array}{l}\text { Like any other contract it consists of terms: amount of a a } \\
\text { commodity, price, delivery date and conditions (rights, } \\
\text { obligations, fees) }\end{array}$ & $\begin{array}{l}\text { Underlying asset; strike/ expercise price; } \\
\text { expiration date/ expiry; premium }\end{array}$ \\
\hline $\begin{array}{l}\text { How does it function? } \\
\text { (telic) }\end{array}$ & Insure against risks and speculate. & Hedge; speculate \\
\hline $\begin{array}{l}\text { How is it used? } \\
\text { (agentive) }\end{array}$ & It is bought or sold on the OTC market or exchanges & Write; take \\
\hline
\end{tabular}

After we see that students understand what an option is (conceptual content) we can introduce the terms used to discuss options (lexical content) and add some more information ${ }^{1}$. The contract to buy an asset is a call option; The contract to sell an asset is a put option; the price of an underlying asset [asset to be bought or sold] is a strike/

\footnotetext{
${ }^{1}$ Additional information is shown in square brackets.
}

exercise price [it remains unchanged during the whole period]; the delivery date is called expiration date/ period/ expiry [European options can be exercised only at the date

the option expires; American options can be exercised at any time up to expiry which is why they are more valuable]; The fee the buyer pays to the seller is called a premium [the seller keeps it whether or not the buyer exercises the option]. The seller of an option is called a 
writer, the buyer may be called a taker. It may also be worthwhile to compare and contrast options with their "peers": forwards, futures, and other financial instruments. Comparing options with futures students will spot the main distinctive feature: an option is a right to buy or sell something, whereas a futures contract is an obligation binding for both parties (difference in the formal function). Further comparison of futures and forwards reveals their distinctive feature: the former are sold on exchanges whereas the latter can be bought only on the over-thecounter markets (difference in the agentive function). The advantages of this mode of explanation become evident if we compare them with dictionary definitions. The Longman Dictionary of Contemporary English describes an option as the "right to buy or sell something at the stated time in the future." It is a good definition because it reveals the essence of the financial instrument, yet it does not expose other features necessary for constructing a concept. Other definitions are even less suitable for our purpose. Some of them are somewhat misleading. For example, futures are explained as contracts "for goods to be bought or sold in large quantities at the present price, but not produced or sent till a later time." It is unclear what is meant by 'the present price': the current market price or the price agreed upon today. As far as the term 'forward' is concerned, there is no lexical entry for the noun at all. The forte of qualia structure is that it reveals the protean properties of a concept.

\section{Concept Development and Cognitive Modeling}

\section{Initial stage of learning}

Further work on the concept which we call 'concept development' involves exposing permanent links of the concept in question. To make it more illuminating we model these relationships with the help of a cognitive model. We explicate the links of a financial instrument with agents who use it, expound its types and uses, desired and eventual results and so on (see Appendix 2). The model designed may vary in depth and diversity depending on the teaching objectives and students' readiness to absorb the information.

1. Agents. The most important thing is to understand the nature of the commitment of buyers and sellers. Buyers have no obligations to do anything. They can simply let the option expire, walk away from it. Sellers, on the contrary, are required to go through with the trade if the buyer wants to exercise the option. Graphically, it may be represented as follows:

\begin{tabular}{|c|c|c|}
\hline \multirow{2}{*}{$\begin{array}{c}\text { WRITER } \\
\text { (Seller) }\end{array}$} & $\begin{array}{c}\text { obligations } \\
\text { BUYER } \\
\text { (Taker) }\end{array}$ \\
\cline { 2 - 2 } & rights & \\
\hline
\end{tabular}

Diagram 1. The Legal Relationship Between the Buyer and the Seller.

2. Benefits. When buying or selling an option both the writer and the buyer want to benefit from it. Benefit to the writer is the PREMIUM he gets and keeps. Benefit to the buyer is INTRINSIC VALUE (the difference between the strike price and the market price) if the buyer guesses right the movement of the market. The other benefit is LEVERAGE which means that a small input of money (premium) opens up to the option holder a possibility of considerable gains.

3. Operations and results. The option buyer has three options: either to exercise the contract or default on it, or resell it on the open market before the expiration date. If the option taker decides to exercise the option, the result may be threefold. If it is advantageous for the holder, he is said to be in-the-money; if it is not advantageous, he is outof-the-money; if the holder neither gains nor loses, he is atthe-money.

4. Types of options and their uses. The writer and the buyer pursue different goals. The buyer may want to hedge possible risks of market volatility or speculate whereas the objective of the seller is outright speculation. In order to hedge risks a cautious investor may buy an option which is called a straddle — a simultaneous purchase of a call option and a put option with the same strike price and expiry date. This strategy is good if markets are extremely volatile and the investor is afraid that his stock will falter or go down. The writer willing to collect a premium and escape going through with the trade has a useful instrument at his disposal - a strangle. It involves writing a call with a very high strike price and a put with a very low strike price which is supposed to discourage any option holder from exercising it.

To consolidate this knowledge, the teacher is to compile the HYRERTEXT by which we understand a collection of excerpts from various sources, including some websites. The main requirement to such texts at the initial level of proficiency is that they should not be beyond students' capabilities or the acquired knowledge base which gives students a sense of achievement. To check whether students understand the nature of options the teacher may ask some questions like how an investor can make money with a put or a call, or what options lead to gains on a bull or bear market.

\section{Advanced stage of learning}

For more than half a century the options markets have displayed dramatic growth as more sophisticated products have been introduced, new trading styles used, and new uses of options have been tested. Innovative products and procedures have given rise to an avalanche of new lexical units. To achieve a better understanding of the subject area and by way of expanding knowledge, we may go beyond the initial stage and introduce a stratum of specialist vocabulary pertaining to advanced knowledge acquisition.

5. Buying and selling styles. The most notable selling styles are covered calls and naked calls. Writing a covered call means selling the right to some other party to buy stocks from you which you already own. A naked call means selling an option that allows someone to buy from you what you don't own. This is more risky because if this person wants to exercise the option, you will have to buy the stocks at the market price in order to sell them at the agreed-upon price (strike price) to the buyer. Also, buying styles present some interest. If an investor is worried about 
price fluctuations of his stock he may buy a married put, that is buy a stock and a put option on this stock at the same time. If the price of the stock goes down, the investor can exercise the option and offset the loss.

6. Market conditions. It is advisable to discuss how investors can make money on spreads - the difference between the purchasing and the selling prices. For example, Bull spread - the purchase of a call option with a low exercise price and the sale of a call option with a relatively high exercise price. "Buy low, sell high" — this strategy is suitable for investors who are bullish. Other types of spreads are: Bear spreads and Butterfly spreads.

7. Brokers' speak. The market has worked out its own expressions of communication between brokers and investors. For example, an investor may give his broker an 'All-or-None' order - a type of option order which requires that the order be executed completely or not at all, or he may give a 'Down-and-Out' order — if the price of the underlying asset falls below a preset level, the option is not exercised. The more units a student learns at this stage, the easier it will be for him to understand professional discourse. It is advisable at this level of proficiency to encourage students to read the press to be in the know what is happening on the derivatives markets.

\section{Conclusion}

In his lectures, I. Kant told his students,"we know only so much as we hold in the memory and we easily forget what we do not understand." Understanding and memorizing are entwined in the construction of knowledge. So, coherent presentation of information to be properly learned is of primary importance. Having assumed that mental modeling is the basis of human knowledge, we have attempted to show, hopefully convincingly, that comprehension-directed teaching at the initial stage of ESP acquisition can make effective use of two cognitive tools: qualia structure and cognitive model. It is worth summing up their advantages and plausibility.

1. As terms play a pivotal role in professional communication and the distinctive feature of terms is the underlying concept, we have tried to find a tool that would optimize concept learning, and we believe that the 'Qualia structure' tool serves this end. Qualia structure is the model we developed in order to expose conceptual nature of a term by partitioning content into four cognitive roles (formal, constitutive, telic and agentive) to give a multifaceted picture and highlight the distinctive properties of the concept. The other part of a term - linguistic content — is represented by various lexical units which mediate conceptual representations in speech.

2. Since any knowledge system functions as a domain, information is stored in long-term memory in organized fashion. Learning of terminology may be effectively enhanced by structuring it via establishing multiple links of the key concepts. The instrument that meets this objective is cognitive model which is a simulation of reality and converts unstructured inventories of knowledge into an intricately knit, co-herent and comprehensible structure.

Arguedly, these tools should be used judiciously and employed only if they serve the purpose of clarification. Nevertheless, we believe that they serve well the purpose of constructing knowledge at the initial stage and take language learning and teaching to a higher, more sophisticated level. Though it might seem a tall order, learning outcomes may prove rewarding.

\section{References}

1. Anderson, R. C. et al., 2001. Four Types of Knowledge. .http://www. scribd.com/doc/14554355/Knowledge-Types-Revised. [Accessed 1509 2010]

2. Anderson, R. C., 1977. The Notion of Schemata and the Educational Enterprise. In Anderson, R. C., Spiro, R. J., \& Monatague, W. E. (eds.) Schooling and the Acquisition of Knowledge. Lawrence Erlbaum Associates, Hillsdale: N.J, pp.415-431.

3. Archibald, J., 1997. Second Language Acquisition. In: Contemporary Linguistics. London \& New York: Longman, pp.503-539.

4. Aristotle, 1998. The Metaphysics. London: Penguin Books

5. Bregman, A. S., 1977. Perception and Behavior as Compositions of Ideals. In Cognitive Psychology, 9, pp.250-292.

6. Burleson, B. R., 1987. Cognitive Complexity. In McCroskey, J. C.\&. Daly, J. A. (eds.) Personality and Interpersonal Communication., Newbury Park CA: Sage, pp.305-349.

7. Croft, W., Cruse, A. D., 2004. Cognitive Linguistics, Cambridge: Cambridge University Press.

8. Derry, S., 1990. Cognitive Model of Learning. http://www.longleaf.net/ ggrow/StrategicReader/StratModel.html [Accessed 15.09 2010].

9. Derry, S., 1996. Cognitive Schema Theory in the Constructivist Debate. In Educational Psychologist, 31(3/4), pp.163-174.

10. Ericsson, K. A. \& Smith, J. (eds.), 1991. Toward A General Theory Of Expertise: Prospects and limits. New York: Cambridge University Press.

11. Evans, V., 2009. How Words Mean: Lexical Concepts, Cognitive Models and Meaning Construction. Oxford: Oxford University Press.

12. Fillmore, C. J., 1982. Frame Semantics. In Linguistics in the Morning Calm. Seoul: Hanshin Publishing Co, pp.111-137.

13. Geeraerts, D., 2006. A Rough Guide To Cognitive Linguistics. In Langacker, R. W., Geeaerts, D., Dirven, R., Taylor, J. R. (eds.) Cognitive Linguistics Research 34. Berlin, New York: Mouton de Gruyter.

14. Hoffman, R. R., 1992. The Psychology of Expertise: Cognitive and Empirical Research. New York: AI. Springer-Verlag.

15. Kant, I., 1908. The Educational Theory of Immanuel Kant. Translated and Edited by Edward Franklin Buchner. Philadelphia, U.S.A.: Lippincott Company.

16. Kelly, G. A., 1955. Principles of Personal Construct Psychology. New York: Norton.

17. Lakoff, G., Johnson, M., 1980. Metaphors We Live By. Chicago: University of Chicago Press.

18. Lakoff, G., 1987. Cognitive Models and Prototype Theory. In Ulric Neisser (ed). Concepts and Conceptual Development: Ecological and Intellectual Factors in Categorization. New York: Cambridge University Press, pp.63-100.

19. Lewis, C. I., 1929. Mind and the World Order: Outline of a Theory of Knowledge. New York: Charles Scribners.

20. Locke, J., 1849. An Essay Concerning Human Understanding. 13 ed. Cheapside, London: William Tegg \& Co.

21. O'Grady, W., 1997. Semantics: the Analysis of Meaning. In: Contemporary Linguistics. London \& New York: Longman, pp.267-312.

22. Paivio, A., 1990. Mental Representations: a Dual Coding Approach, Oxford: Oxford University Press,.

23. Pustejovsky, J., 2001. The Generative Lexicon. Massachusetts Institute of Technology.

24. Schank, R. C, Abelson, R., 1977. Scripts, Plans, Goals, and Understanding, Earlbaum Assoc. New York: Hillsdale. 
25. Thagard, P., 2005. Mind. Introduction to Cognitive Science. Second edition, Massachusetts: MIT.
26. Wüster, E., 1974. General Terminology Theory — Fine Line between Linguistics, Logic, Ontology, Information Science and Business Sciences. In Linguistics (119), pp.61-106.

Natalya Davidko

Kognityvinis požiūris ị anglų kalbos specialiems tikslams dèstymą

Santrauka

Šio straipsnio tikslas yra aptarti, kaip dvikalbiai studentai įsisavina specializuotas žinias. Straipsnyje pateikiama trumpa įvairaus tipo žinių ir jų ịsisavinimo dabartinių traktuočių apžvalga. Pabrěžiama žinių, kaip pirminès sąlygos tolesniam mokymuisi ir bendravimui, svarba. Teorinis siūlomo požiūrio pamatas randasi iš šiuolaikinio kognityvinio mokslo, taip pat iš filosofijos žinių, kurios stipriai remiasi 17 ir 18 amžių empirikų darbais. Žinios yra kaupiamos kaip mentalinès reprezentacijos, kurios turi konceptualujjị ir lingvistinị turinị. Terminai yra specifiniai vienetai, kuriuose konceptualaus ir lingvistinio turinio užduotis yra taip išreikšta, kad i ją negalima neatsižvelgti mokymo procese. Konceptualiojo turinio aiškinimui yra naudojama qualia struktūra. Kitas kognityviniame mokyme naudojamas įrankis yra „kognityvinis modelis“, kurio tikslas yra išsiaiškinti konceptualius organizuojančius principus, sukuriant dauginius ryšius su kitomis sąvokomis. Tikètina, kad šie veiksmai gali būti taikomi bet kurioje verslo terminologijos srityje.

Straipsnis įteiktas 201006 Parengtas spaudai 201012

\section{The author}

Natalya Davidko, PhD, associated professor, lecturer at Moscow Institute TOURO (MIT), head of the Humanities department,

Academic interests: Linguistics: Language and business, business terminology, cognitive linguistics. Didactics: teaching English as Second Language. Address: 20 Podsosensky Pereulok, Moscow, Russia,

E-mail: natalyadavidko@yandex.ru; DavidkoNatalya@touro.ru.

\section{APPENDIXES}

Appendix 1. Samples of Texts Analyzed

\begin{tabular}{|c|c|c|}
\hline TEXTBOOK: & MANUAL: & INVESTOPEDIA \\
\hline $\begin{array}{l}\text { "Investors who buy options acquire } \\
\text { nothing more than the right to subse- } \\
\text { quently buy or sell another related } \\
\text { asset. That is, an option gives the } \\
\text { holder the right to buy or sell a } \\
\text { certain amount of the underlying } \\
\text { asset at a specified price (strike or } \\
\text { exercise price) over a specified } \\
\text { period of time (expiration date). } \\
\text { Options are contractual instruments } \\
\text { whereby two parties enter into a con- } \\
\text { tract to give something of value to } \\
\text { each other. The option buyer has the } \\
\text { right to buy or sell the underlying } \\
\text { asset. The option seller stands ready } \\
\text { to sell or buy the underlying asset } \\
\text { according to the terms of the contract } \\
\text { for which the seller has been paid a } \\
\text { certain amount of money (premium). } \\
\text { Much of the popularity of options } \\
\text { stems from the fact investors can buy } \\
\text { a lot of price action with a limited } \\
\text { amount of capital (leverage) and al- } \\
\text { ways enjoying limited exposure to } \\
\text { risk. A put enables the holder to sell } \\
\text { the underlying security, a call, in } \\
\text { contrast, gives the holder the right to } \\
\text { buy the securities. } \\
\text { Puts and calls are a unique type of } \\
\text { security because they are not issued } \\
\text { by organizations that issue the un- } \\
\text { derlying stock or financial asset. In- } \\
\text { stead, they are created by investors. } \\
\text { The individual writing an option is } \\
\text { known as the option maker or writer. }\end{array}$ & $\begin{array}{l}\text { Hedging Instruments } \\
\text { "An option contract conveys the right, but not the } \\
\text { obligation, to either buy or sell a commodity at a } \\
\text { fixed price at a fixed future date or at any time } \\
\text { during a fixed future period. An option to purchase } \\
\text { is a call option; an option to sell is a put option. The } \\
\text { price at which the option can be exercised is known } \\
\text { as a strike or exercise price. } \\
\text { The purchaser (or taker) will pay a premium for the } \\
\text { right to exercise the option. In exchange for the } \\
\text { premium, the purchaser will limit his risk to the } \\
\text { price volatility whilst retaining unlimited potential to } \\
\text { profit if price movements are favorable. The writer } \\
\text { of the option in return for taking on unlimited risk } \\
\text { receives the premium. } \\
\text { Where it would be advantageous for the holder to } \\
\text { exercise the option, the option is said to be 'in the } \\
\text { money'. An option is 'out of the money' if the } \\
\text { exercise is not advantageous. An option is 'at the } \\
\text { money' where the market value of the underlying } \\
\text { transaction is equal to the strike price. And finally, } \\
\text { DOOM - deep out of the money" } \\
\text { (The Financial Jungle - Guide to Financial } \\
\text { Lost in a maze of hedges } \\
\text { "Volatile exchange rates in recent weeks have sent } \\
\text { many a nervous boss scurrying to his finance } \\
\text { department to check up on its currency-hedging } \\
\text { strategy. ... } \\
\text { Few firms can hedge all, or even most, of their risk } \\
\text { naturally. So many hedge actively in the financial } \\
\text { markets, mainly using forward contracts and }\end{array}$ & $\begin{array}{l}\text { An option is a contract that gives the buyer the right, but not } \\
\text { the obligation, to buy or sell an underlying asset at a specific } \\
\text { price on or before a certain date. An option, just like a stock } \\
\text { or bond, is a security. } \\
\text { The contract has two very important points. First, when you } \\
\text { buy an option, you have a right but not an obligation to do } \\
\text { something. You can always let the expiration date go by, at } \\
\text { which point the option becomes worthless. If this happens, } \\
\text { you lose } 100 \% \text { of your investment, which is the money you } \\
\text { used to pay for the option (premium). Second, an option is } \\
\text { merely a contract that deals with an underlying asset. For } \\
\text { this reason, options are called derivatives, which means an } \\
\text { option derives its value from something else. } \\
\text { The two types of options are calls and puts: A call gives the } \\
\text { holder the right to buy an asset at a certain price within a } \\
\text { specific period of time. A put gives the holder the right to } \\
\text { sell an asset at a certain price within a specific period of } \\
\text { time. } \\
\text { There are four types of participants in options markets } \\
\text { depending on the position they take: } \\
\text { 1. Buyers of calls } \\
\text { 2. Sellers of calls } \\
3 . \text { Buyers of puts } \\
4 \text {. Sellers of puts } \\
\text { People who buy options are called holders and those who } \\
\text { sell options are called writers; } \\
\text { Here is the important distinction between buyers and } \\
\text { sellers:-Call holders and put holders (buyers) are not } \\
\text { obligated to buy or sell. They have the choice to exercise } \\
\text { their rights if they choose. } \\
\text { Call writers and put writers (sellers), however, are obligated } \\
\text { to buy or sell. } \\
\text { The Lingo }\end{array}$ \\
\hline
\end{tabular}


He can now sell the option in the market. The put or call now is a fullfledged financial asset and trades in the open market like any other security.

For the most part, options are used in three different kinds of trading strategies: (1) buying put and calls for speculation, (2) hedging with puts and calls, (3) option writing and spreading."

(Gitman, L. J. \& Joennk, D., 2005.

Fundamentals of Investing $\left(9^{\text {th }}\right.$ edition), Boston, pp.641-642.

\section{options...}

The trouble with forward contracts is that they are irrevocable. Options - which give firms the right, but not the obligation, to use a particular forward contract - are more flexible. Imagine that a British exporter buys a put to sell dollars in three months at a forward rate. If the exchange rate moves against the firm, it can exercise its option and limit the damage; it the rate goes in its favor, it can let the option lapse and enjoy the windfall. ...

Firms seem to use forward contracts twice as much as options. One reason is cost. Options are expensive and must be paid for whether or not they are used."

(The Economist, Oct $3^{\text {rd }} 1992$, p.76.)
To trade options, you'll have to know the terminology associated with the options market.

The price at which an underlying stock can be purchased or sold is called the strike price. This is the price a stock price must go above (for calls) or go below (for puts) before a position can be exercised for a profit. All of this must occur before the expiration date.

An option that is traded on a national options exchange such as the Chicago Board Options Exchange (CBOE) is known as a listed option.

(http://www.investopedia.com/university/options/option.asp)

Appendix 2. Cognitive Model of the Options Domain

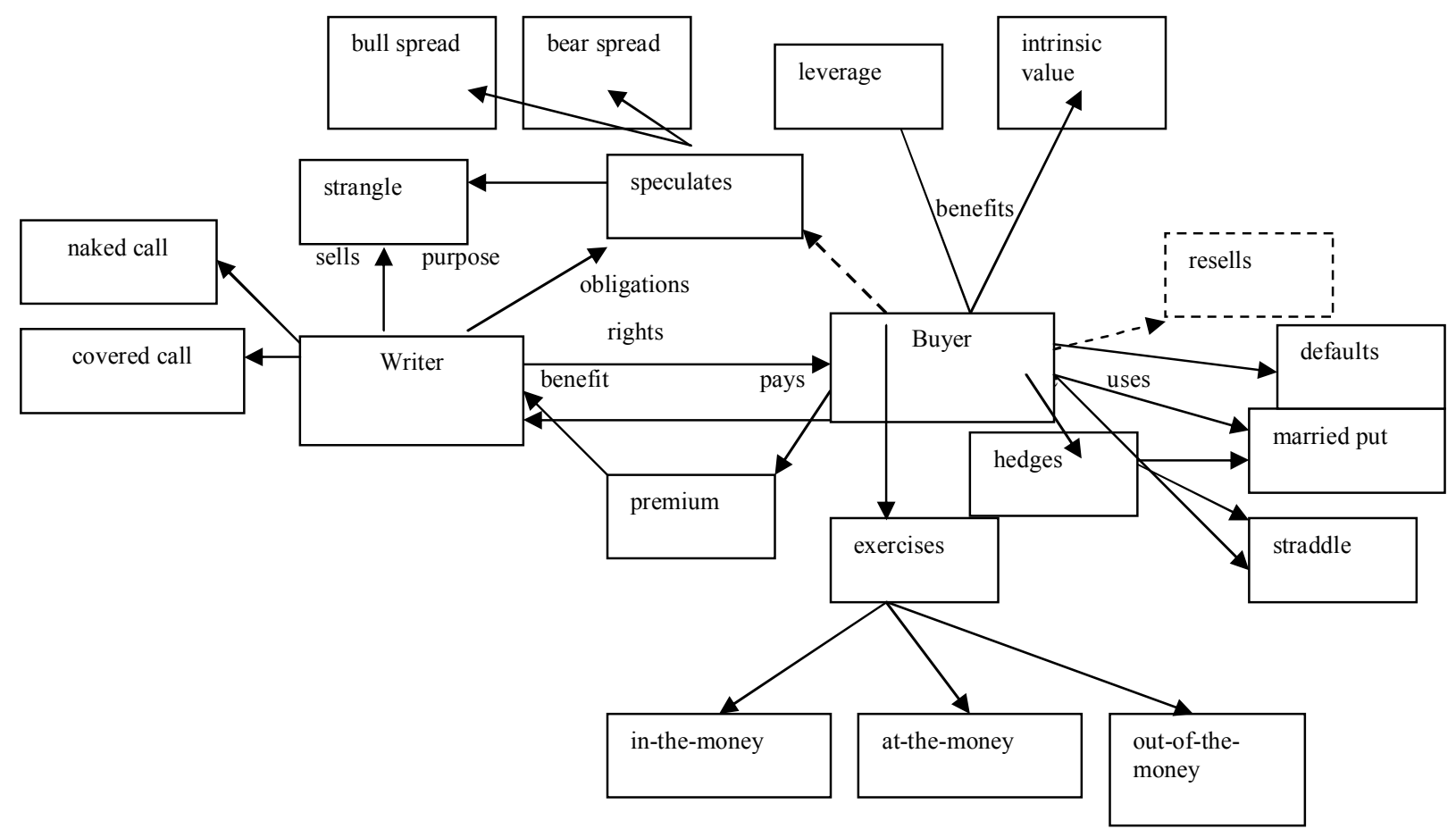

